\title{
Correction to: Efficient in vitro plant regeneration from leaf-derived callus and genetic fidelity assessment of an endemic medicinal plant Ranunculus wallichianus Wight \& Arnn by using RAPD and ISSR markers
}

\author{
P. Srinivasan ${ }^{1}\left[\right.$ (1) H. David Raja ${ }^{1} \cdot$ R. Tamilvanan ${ }^{1}$
}

Published online: 9 August 2021

(c) Springer Nature B.V. 2021

\section{Correction to: \\ Plant Cell, Tissue and Organ Culture (PCTOC) \\ https://doi.org/10.1007/s11240-021-02134-y}

In Table 1 of this article, the NAA concentration in the bottom three entries of the 4th column were incorrectly specified and should be 0.5 . The original article has been corrected.

Publisher's Note Springer Nature remains neutral with regard to jurisdictional claims in published maps and institutional affiliations.

The original article can be found online at https://doi.org/10.1007/ s11240-021-02134-y.

\section{P. Srinivasan}

karuppusrini@gmail.com

1 Department of Botany, Gnanarethinam Centre for In vitro Conservation (GCIC), St. Joseph's College, Affiliated to Bharathidasan University, Tiruchirappalli, Tamil Nadu 620 002, India 